\title{
Enhancing the Quality of Student Research by an On-going Multiple-Project- Based Course
}

\section{Dr. Chaomin Luo, University of Detroit Mercy}

Dr. Chaomin Luo received his Ph.D. degree in Dept of Electrical and Computer Engineering at University of Waterloo, in 2008, his M.Sc. degree in Engineering Systems and Computing at University of Guelph, Canada, and his B.Eng. degree in Electrical Engineering from Southeast University, Nanjing, China. He was an Assistant Professor in Electrical Engineering, National Taipei University in 2008. He is currently Associate Professor in the Dept of Electrical Engineering, at University of Detroit Mercy. He was the Publicity Chair in 2011 IEEE International Conference on Automation and Logistics. He was on the Conference Committee in 2012 International Conference on Information and Automation and International Symposium on Biomedical Engineering and Publicity Chair in 2012 IEEE International Conference on Automation and Logistics. He is currently a Chair of IEEE SEM - Computational Intelligence Chapter a Vice Chair of IEEE SEM- Robotics and Automation and Chair of Education Committee of IEEE SEM. He has extensively published in reputed journal and conference proceedings, such as IEEE Transactions on Neural Networks, IEEE Transactions on SMC, IEEE-ICRA, and IEEE-IROS, etc. 


\title{
Enhancing the Quality of Student Research by an On-going Multiple-Project-Based Course
}

\author{
Chaomin Luo \\ Department of Electrical and Computer Engineering \\ University of Detroit Mercy, Michigan, USA
}

\section{Introduction}

With the continued advances in computational intelligence over the several decades, it is becoming increasingly vital that development of a new course curriculum on computational intelligence and soft computing in a university will contribute to technology advancements and applications [1,2]. With the advance of increasingly faster computing hardware and cheaper memory chips, computational intelligence, a relatively new field of application in engineering, is becoming increasingly important in many engineering disciplines including robotics. ELEE4400/5400 Computational Intelligence Techniques that is a new curriculum teaches Electrical Engineering students to understand basic computational intelligence techniques including neural networks, bioinspired systems, fuzzy logic, simulated annealing, genetic algorithms and swarm intelligence. It aims to design, model, and simulate computational intelligence models for engineering applications, especially, research on mobile robotics. It is important to emphasize that this course differs from the traditional theoretical-based engineering course. The main focus is on teaching students to perform engineering and research projects to meet the required specifications while applying computational intelligence techniques for autonomous robots or other applications.

A series of well-prepared projects assigned to students to cover various topics in this course assist in student learning for enhancement of research skills. Teaching and learning strategies by the projectbased methodology were associated with ABET learning outcomes intended to improve student research capability [3]. In this on-going project, the objective is to perform an in-depth technical research consisting of multiple projects utilized on robot navigation, motion planning and mapping applications. Opinions of students toward project-based course were acquired by questionnaires at the end of the course to evaluate its dedication to student research. The teaching quality of projectbased course with regard to student research usually was assessed by course materials, student evaluation, project demonstration, presentation, and interviews with students.

Students understand various intelligent system models such as artificial neural networks, simulated annealing, genetic algorithms, and swarm intelligence in the class, while corresponding project assignments are assigned to students to apply the models they have learned to resolve researchconcentrated electrical engineering problems. Results of learning outcomes and assessment indicate that the on-going multiple-project-based pedagogy is effective and efficient to enhance the quality of student research. Assessment in the shape of milestone interviews, final presentation, surveys, project demonstration and instructor observation will be discussed in this paper. More precisely, 
multiple projects as a variety of milestones are assigned to students in this curriculum to enhance student learning of concepts, and research ability. Based on these multiple projects, students are expected to develop a composite system by employing computational intelligence techniques for robotic motion planning and navigation applications. In this project-based course, multiple-project is intended to be designed to train the following research skills of students: (1) knowing current work in field, (2) recognizing research problems, (3) critical thinking, (4) problem-resolving, (5) research methods, (6) critical reviewing, and (7) documenting and reporting.

\section{The On-going Multiple-project-based Pedagogy}

The Department of Electrical and Computer Engineering in our school offers track concentration on the Robotics and Mechatronics program. A variety of practical research and development projects are crucial features of the Robotics and Mechatronics program. Therefore, Computational Intelligence course with on-going practical $R \& D$ project is a great opportunity for students to enhance their research experience. ELEE4400/5400 Computational Intelligence Techniques is an elective course offered for upper-level undergraduates and graduate students. Undergraduate students have the opportunity to undertake postgraduate-level elective curriculums in their final year of study. Concepts and algorithms are introduced in the classroom. However, projects will subsequently be assigned to students to provide them practical research experience.

The fundamental idea of on-going multi-project course teaching and learning through an on-going multiple-project is to decompose a large project into a series of projects that have synergistic connection. The previous project lays the foundation for the subsequent projects. Most importantly, the following research skills, should be embedded into the small projects, such as, knowing current work in field, recognizing research problems, critical thinking, problem-resolving, research methods, critical reviewing, and documenting and reporting. In this class, it is crucial to integrate innovative teaching methodologies, student learning strategies, team activities, milestone track, and faculty involvement together for the on-going project to maximize the teaching and learning effectiveness in research. The entire research project is decomposed into several small projects that are relatively independent and also relevant. Definition and design of this project by the instructor primarily emphasize on the following aspects: (i) every small project can contribute to the entire project; (ii) every project can be assigned to students after one or two weeks the concepts related to this project have been taught in the classroom; (iii) students should be aware of the connections between these small projects; (iv) every small project is feasible to be fulfilled in a controllable pre-defined schedule; (v) every small project is manageable in a team mode; and (vi) every small project is applicable to cover the principal topics taught in the classroom.

\subsection{The Project Objective}

The primary objective of the multi-stage project for student research is to develop efficient computational intelligence algorithms and implementations for real-time motion control and navigation of mobile robots in unknown environments. In this project, students are assigned multiple projects to aid them in developing a sequence of algorithms and finally, it is integrated into 
one final project for motion control, navigation and mapping of autonomous robots. Each project assignment is scheduled after one or two weeks when the corresponding theoretical concepts and algorithms are introduced so that students are capable of applying what they have learned in the classroom into the projects. There are five decomposed sub-tasks, each of which may be called a sub-project summarized in Table 1.

Table 1 The project assignments and their description

\begin{tabular}{|c||l|}
\hline Project & Description \\
\hline \multirow{3}{*}{$\mathrm{P}_{1}$ : Perceptron } & $\begin{array}{l}\text { Perceptron method is employed to organize, identify and interpret } \\
\text { sensory information to represent and understand the environment. } \\
\text { Artificial neural networks model is associated with the perception } \\
\text { project. Literature review on robot navigation and motion planning }\end{array}$ \\
\hline \multirow{3}{*}{$\mathrm{P}_{2}$ : Wave propagation } & $\begin{array}{l}\text { Wave propagation serves as a global path planner by distance } \\
\text { transformation method to find an optimal trajectory in known } \\
\text { environments, in which the map information is predefined. }\end{array}$ \\
\hline $\mathrm{P}_{3}:$ Simulated annealing & $\begin{array}{l}\text { Simulated annealing is utilized to model the local navigator of an } \\
\text { autonomous robot. SA is intended to find an optimal local path with } \\
\text { obstacle avoidance }\end{array}$ \\
\hline $\mathrm{P}_{4}$ : GA-based method & $\begin{array}{l}\text { Genetic algorithm is expected to be a real-time navigator to search and } \\
\text { find a near-optimal trajectory }\end{array}$ \\
\hline \multirow{3}{*}{$\mathrm{P}_{5}:$ Fuzzy logic } & $\begin{array}{l}\text { A fuzzy logic-based real-time navigation model developed in } \\
\text { combination with the motion planning and trajectory following with } \\
\text { obstacle avoidance as an integrated and coordinated unit }\end{array}$ \\
\hline Final project & $\begin{array}{l}\text { In this Stage, students have capability to integrate some of sub-projects } \\
\text { into one project to test its applicability and effectiveness for a real-time } \\
\text { mobile robot navigation and motion planning systems. It will contain } \\
\text { final presentation, documentation and demonstration }\end{array}$ \\
\hline
\end{tabular}

Amongst the five small on-going projects, Project 1 with notion of $\mathrm{P}_{1}$ (Perceptron) is a relatively independent project intended to obtain environmental information by sensors of a mobile robot. It should be noted that literature review, an important aspect in research skills, on robot navigation and motion planning is required in this milestone. Project $2\left(\mathrm{P}_{2}\right.$ : Wave propagation) assists student in construction of a global trajectory of a mobile robot, in which students are capable of practicing motion planning programming in a known environment. Proejct $3\left(\mathrm{P}_{3}\right.$ : Simulated annealing) is designed to provide students with local navigator development experience of a mible robot by instructed one of most powerful computational intelligence teachniques, simulated annealing. Project 4 ( $\mathrm{P}_{4}$ : GA-based method) is a global path planner based on genetic algorithms, which allows students better understand motion control by GA model. Objective of Project 5 ( $\mathrm{P}_{5}$ : Fuzzy logic) is to develop a local nvaigtor with obstacle avoidance under unknown envirnonments. 
Finally, combinations of several projects are following to enphsize research enhancment of students: (i) Project 2 as a global path planner is integrated with Project 3 or Project 5 to form a real-time autonomous mobile robot motion planning system in a known environment; (ii) Project 4 as a global path planner is combined with Project 3 or Project 5 to construct a real-time autonomous mobile robot navigation system in an unknown environment; or (iii) Project 2 as a global path planner is jointed with Project 4 to construct a real-time autonomous mobile robot navigation system in known environments for comparison purpose.

\subsection{Project Progress by the Milestone Model}

This is a challenging mission to design an effective method to assure multiple projects success. The project is one-semester lone thus its project management is essential in implementation of such a project-based curriculum. Effectiveness of project management through a milestone strategy has been proven to efficiently maintain project progress as a tool. Milestone model signals specific time points along this project timeline. The anchors such as a project starting point, sub-tasks, targets and end date, are marked. In this mode, the entire mission is decomposed into sub-tasks in a sequential, phase-wise manner where sequential requirements are gathered at various stages. Students are required to have a milestone interview with the instructor and submit their milestone reports by due dates, on a weekly basis. However, weekly-based interview timeline may be interrupted with reasonable reasons such as exacting results found before an interview. By means of the proposed milestone mode, the project was managed effectively.

Table 2 The milestone tasks, progress and performance analysis in milestone mode

\begin{tabular}{|c|c|c|c|c|}
\hline \multirow[b]{2}{*}{$\begin{array}{l}\text { Milestone } \\
\text { Sequence }\end{array}$} & \multirow[b]{2}{*}{$\begin{array}{l}\text { Milestone } \\
\text { Tasks }\end{array}$} & \multirow{2}{*}{$\begin{array}{l}\text { Percentage } \\
\text { Milestone } \\
\text { Progress } \\
(\%)\end{array}$} & \multicolumn{2}{|c|}{ Performance Analysis } \\
\hline & & & $\begin{array}{l}\text { Motivating } \\
\text { factors }\end{array}$ & $\begin{array}{l}\text { De-motivating } \\
\text { factors }\end{array}$ \\
\hline $\mathrm{M}_{1}$ & $\begin{array}{l}\text { Understanding perceptron } \\
\text { and program to implement it }\end{array}$ & 85 & $\begin{array}{l}\text { Assistance and } \\
\text { encouragement }\end{array}$ & $\begin{array}{l}\text { Difficulty in } \\
\text { understanding } \\
\text { concepts of } \\
\text { perceptron }\end{array}$ \\
\hline $\mathrm{M}_{2}$ & $\begin{array}{l}\text { Develop wave propagation } \\
\text { model for global motion } \\
\text { planning of a mobile robot }\end{array}$ & 95 & $\begin{array}{l}\text { Significance of } \\
\text { research project; } \\
\text { Assistance and } \\
\text { encouragement }\end{array}$ & $\begin{array}{l}\text { Difficulty in } \\
\text { debugging }\end{array}$ \\
\hline $\mathrm{M}_{3}$ & $\begin{array}{l}\text { Based on sampling code of } \\
\text { SA model, revise it to local } \\
\text { navigator of a mobile robot, } \\
\text { tune various parameters of } \\
\text { SA }\end{array}$ & 90 & $\begin{array}{l}\text { Significance of } \\
\text { research project; } \\
\text { Benefits from the } \\
\text { lectures taught in } \\
\text { classroom }\end{array}$ & $\begin{array}{l}\text { Difficulty in } \\
\text { debugging; } \\
\text { Team } \\
\text { communication }\end{array}$ \\
\hline & $\begin{array}{l}\text { Based on GA code given by } \\
\text { the instructor, revise it to }\end{array}$ & 80 & $\begin{array}{l}\text { Assistance and } \\
\text { encouragement; }\end{array}$ & $\begin{array}{l}\text { Difficulty in } \\
\text { understanding of }\end{array}$ \\
\hline
\end{tabular}




\begin{tabular}{|l||l|l|l|l|}
\hline $\mathrm{M}_{4}$ & $\begin{array}{l}\text { trajectory planning of a } \\
\text { mobile robot, debug various } \\
\text { parameters of GA }\end{array}$ & $\begin{array}{l}\text { Benefits from the } \\
\text { sampling code } \\
\text { and lectures in } \\
\text { classroom }\end{array}$ & $\begin{array}{l}\text { concept of GA; } \\
\text { Difficulty in } \\
\text { debugging }\end{array}$ \\
\hline $\mathrm{M}_{5}$ & $\begin{array}{l}\text { Develop Fuzzy logic } \\
\text { controller for obstacle } \\
\text { avoidance under unknown } \\
\text { environments }\end{array}$ & 90 & $\begin{array}{l}\text { Assistance and } \\
\text { encouragement; } \\
\text { Programming } \\
\text { experience }\end{array}$ & Heavy workload \\
\hline $\mathrm{M}_{6}$ & $\begin{array}{l}\text { System integration; } \\
\text { Integrate several small } \\
\text { projects into an efficient } \\
\text { project }\end{array}$ & 95 & $\begin{array}{l}\text { Assistance and } \\
\text { encouragement; } \\
\text { Team work }\end{array}$ & $\begin{array}{l}\text { System integration } \\
\text { experience } \\
\text { insufficiency }\end{array}$ \\
\hline $\begin{array}{l}\text { Final } \\
\text { Presentati } \\
\text { on and } \\
\text { Demo }\end{array}$ & $\begin{array}{l}\text { Presentation, } \\
\text { Documentation, } \\
\text { Demonstration }\end{array}$ & 100 & $\begin{array}{l}\text { Significance of } \\
\text { project; } \\
\text { Team work }\end{array}$ & $\begin{array}{l}\text { Time management } \\
\text { experience }\end{array}$ \\
\hline
\end{tabular}

Milestone outcomes and reports are completely marked and interviews are carried out, which are summarized in Table 2. In this table, milestone tasks, percentage of progress made, and performance analysis are available for us to better understand student learning activity, manage the project and assure student progress. Performance analysis indicates motivating factors for students to successfully complete the milestone tasks, and also barriers to cause postponement to complete the research projects. According to Table 2, "significance of research project" and "assistance and encouragement from the instructor and TA" are two positive factors to make significant progress. "Difficulty in debugging" is the top reason having a negative influence on the project progress. Additionally, learning quality in terms of research activity by self-assessment from students and performance analysis by interviews will be addressed in the following sections. Some other measures to improve the quality of teaching and learning involve student debugging notebook, research paper reading, team meetings, discussion with the instructor and highly-organized documents. A successful simulation result by Project 5 is illustrated in Figure 1, in which a mobile robot trajectory is generated by developed Fuzzy Logic model by students.

\subsection{Project Progress by Student Performance Analysis}

In this section, it presents the methodology by performance analysis to take control of project progress. The multi-project based pedagogy can be implemented and evaluated by student performance analysis such as mistakes made by students. Students inevitably make mistakes or have weakness in each sub-project. The mistakes can be employed to improve students' research capability by classifying, ranking and analyzing these mistakes thereby, actions to help students avoid mistake can be taken in the subsequent sub-projects. Correspondingly, the mistakes can be utilized as clues to revise the project formulation, requirements, lecture materials, and outcomes so as to assist in strengthening research ability of students and improving teaching quality. 
It reveals that course materials to be of high quality in guiding their on-going research projects benefit for student progress by revising lecture notes, based on mistakes of students. We have discovered that students highly motivated by on-going multiple-project-based curriculum to strengthen their research capability improve their research potential by correcting their own mistakes. The revised lecture materials work smoothly to develop students' research skills by keeping track of their project progress. Such student research skills consist of literature retrieval, information analysis, team player, creativity, argumentation, oral and written communication, and timing management. Technique skills to be enhanced contain design methodology, debugging, troubleshooting, coding, software architecture, and algorithm design, etc.

In Table 3, mistakes made in each milestone and corresponding actions taken to improve the learning quality by performance analysis are summarized. The improvement of student performance is shown in Table 3 by reduction of percentage of student mistakes made (please see the second column in Table 3).

Table 3 The improvement by milestone performance analysis

\begin{tabular}{|c|c|c|}
\hline $\begin{array}{l}\text { Milestone } \\
\text { Sequence }\end{array}$ & $\begin{array}{l}\text { Mistakes (percentage of mistakes made } \\
\text { by students) }\end{array}$ & Actions taken for improvement \\
\hline \multirow{3}{*}{$\mathrm{M}_{1}$} & $\begin{array}{l}\text { Delivered incomplete milestone report } \\
(40 \%)\end{array}$ & Revision of lecture materials \\
\hline & $\begin{array}{l}\text { Failed to define weights for Rosenblatt } \\
\text { perceptron model }(90 \%)\end{array}$ & $\begin{array}{l}\text { Reinforcement of the explanation in } \\
\text { lecture }\end{array}$ \\
\hline & $\begin{array}{l}\text { Failed to create map of workspace } \\
(60 \%)\end{array}$ & Enhancement of team discussion \\
\hline \multirow{2}{*}{$\mathrm{M}_{2}$} & $\begin{array}{l}\text { Delivered incomplete milestone report } \\
(5 \%)\end{array}$ & $\begin{array}{l}\text { Enhancement of team discussion; } \\
\text { Revision of lecture materials }\end{array}$ \\
\hline & $\begin{array}{l}\text { Failed to make map of workspace } \\
(10 \%)\end{array}$ & Revision of lecture materials \\
\hline \multirow[b]{2}{*}{$\mathrm{M}_{3}$} & Failed to meet the deadline ( $30 \%)$ & $\begin{array}{l}\text { Revision of lecture materials for more } \\
\text { detailed assistance }\end{array}$ \\
\hline & $\begin{array}{l}\text { Failed to understand SA as local } \\
\text { navigator clearly }(35 \%)\end{array}$ & $\begin{array}{l}\text { One excellent student discusses } \\
\text { successful implementation of sub-project }\end{array}$ \\
\hline \multirow[t]{2}{*}{$\mathrm{M}_{4}$} & Failed to meet the deadline ( $5 \%)$ & $\begin{array}{l}\text { Assistance and encouragement; } \\
\text { Coverage of timing and project } \\
\text { management }\end{array}$ \\
\hline & $\begin{array}{l}\text { Failed to tune the parameters of GA } \\
\text { model }(25 \%)\end{array}$ & $\begin{array}{l}\text { Benefits from the sampling code and } \\
\text { lectures in classroom }\end{array}$ \\
\hline $\mathrm{M}_{5}$ & $\begin{array}{l}\text { Failed to make efficient debugging } \\
\text { progress }(40 \%)\end{array}$ & $\begin{array}{l}\text { Revision of lecture materials to provide } \\
\text { more sample coding and explanations }\end{array}$ \\
\hline
\end{tabular}




\begin{tabular}{|l||l|l|}
\hline \multirow{2}{*}{$\mathrm{M}_{6}$} & $\begin{array}{l}\text { Failed to seamlessly integrate fuzzy } \\
\text { model, GA algorithms with global path } \\
\text { planner }\end{array}$ & $\begin{array}{l}\text { Review design methodology, fuzzy } \\
\text { algorithms and GA model; } \\
\text { More coverage of techniques }\end{array}$ \\
\cline { 2 - 3 } & Failed to run the integrated system & Encouragement of team discussion, \\
\hline $\begin{array}{l}\text { Final } \\
\text { Presentation } \\
\text { and Demo }\end{array}$ & $\begin{array}{l}\text { Failed to deliver a good quality of } \\
\text { presentation t (20\%) }\end{array}$ & $\begin{array}{l}\text { Coverage of more lectures on } \\
\text { presentation skills. }\end{array}$ \\
\cline { 2 - 3 } & $\begin{array}{l}\text { Failed to submit a good quality of final } \\
\text { report (25\%) }\end{array}$ & $\begin{array}{l}\text { Coverage of more lectures on } \\
\text { documentation skills. }\end{array}$ \\
\hline
\end{tabular}

\section{Assessment and Project Evaluation}

This multi-stage project with emphasis on student research is evaluated at the end of semester and during the various milestones. The outcomes of the learning and teaching in engineering education are assessed as well. The project results are disseminated by students and instructors at various hierarchical research events such as college-level student research symposiums, university-level poster sessions in University Research Celebration, national research workshops, and even international conferences.

The Department of Electrical and Computer Engineering collects self-assessment questionnaire from students and the instructor gathers quantitative and qualitative feedbacks from students through survey and interviews. The self-assessment questionnaire covers the questions with regard to the project as well as the entire course that contains a variety of milestone assignments prepared for the design project [5]. The benefits are revealed according to project evaluations, selfassessment and a sequence of interviews.

- Students consider that on-going team-based projects improve their learning skills to resolve engineering issues and enhance their research capability in an algorithm-based context.

- Students perceive that this on-going project with team members enables them to be better team players as coordination and consultation are very crucial to ensure successful completion of the project. They have more opportunities to discuss and share their ideas with peers, instructors, and computer administrators.

- Students discover that this team-based project with training interpersonal skills provides students with more communication opportunities. There are plenty of team meetings, in which students discuss a variety of algorithm development, software design and system integration aspects of this project.

- Students realize that this student-centered, research-featured, team-interactive and instructor-facilitated learning atmosphere is remarkably helpful for engineering leaning experience of student research.

- Students recognize that this multi-stage project encourages their full involvement to conduct the project from initial stage to end. The student's practical ability is exercised, research 
interest is motivated, and creation thought is stimulated by employing self-determination design and development mode in this project.

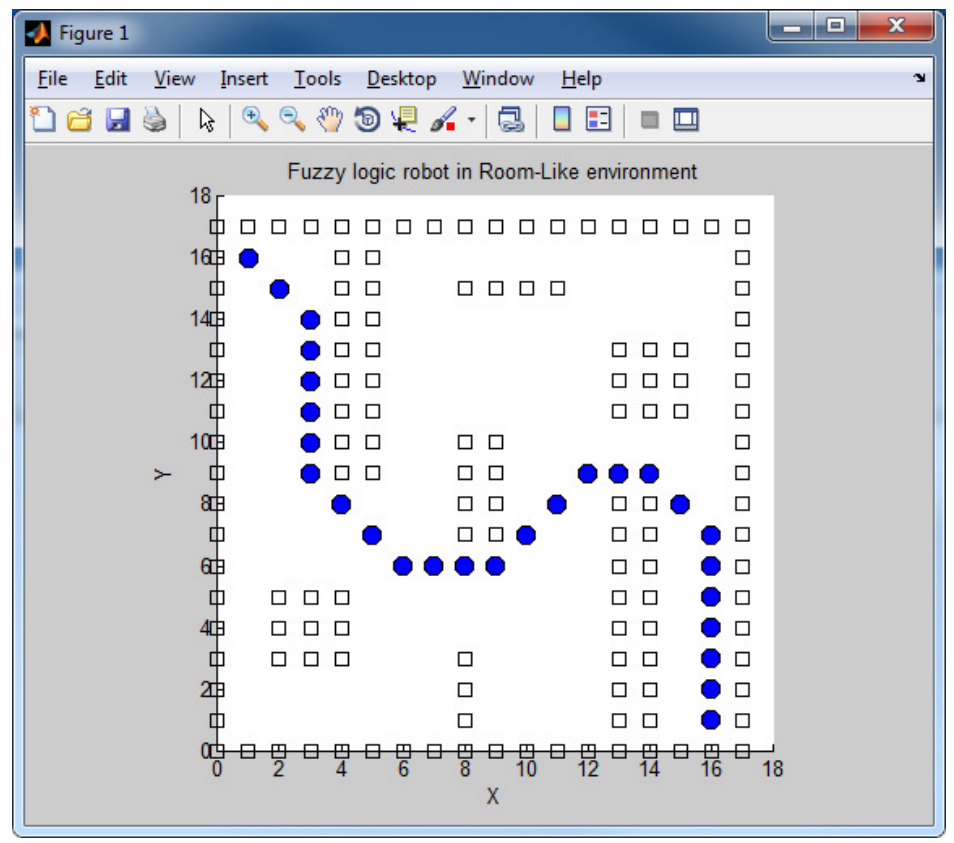

Figure 1 Simulation result of a mobile robot trajectory generated by Fuzzy Logic model

The interactive self-assessments are beneficial to discover the strength and weakness of teaching and learning cycles with research components. The self-assessment was acquired from students in this ELEE4400/5400 as follows corresponding to ABET outcomes [6].

1. Question 1 - "I can understand structures of artificial neural networks and perform training for neural networks and profoundly understand some important learning rules such as Hebbian, Perceptron and Delta learning rules." This assessment is associated with in Outcome e in ABET. Outcome (e): An ability to identify, formulate, and solve electrical engineering problems. In post-project, student survey shows that $83.3 \%$ students strongly agreed and $16.7 \%$ students agreed with the statement, "I can understand structures of artificial neural networks and perform training for neural networks and profoundly understand some important learning rules such as Hebbian, Perceptron and Delta learning rules". $66.7 \%$ students strongly agreed with the statement before the project. $16.7 \%$ students were neutral and $16.7 \%$ students disagreed before fulfillment of project.

2. Question 2 - "I can understand, write and execute C/Matlab programs for application problems by projects to perform artificial neural networks." (Outcome c). Outcome (c): An ability to design electrical systems, components, or processes to meet desired needs. In post-project, student survey shows that $83.3 \%$ students strongly agreed and $16.7 \%$ students agreed with the statement, "I can understand, write and execute C/Matlab programs for application problems by projects to perform artificial neural networks". 50\% students 
strongly agreed with the statement, $16.7 \%$ students were neutral and $33.3 \%$ students disagreed before fulfillment of project.

3. Question 3 - "I profoundly understand how genetic algorithms work and understand the fundamental concepts of genetic algorithms and their variants". (Outcome k). Outcome (k): An ability to use the techniques, skills, and modern engineering tools necessary for electrical engineering practice. In post-project, student survey shows that $83.3 \%$ students strongly agreed with the statement and $16.7 \%$ students were neutral with statement, "I profoundly understand how genetic algorithms work and understand the fundamental concepts of genetic algorithms and their variants". 50\% students strongly agreed with the statement, $33.3 \%$ students were neutral and $16.7 \%$ students disagreed before completion of project.

4. Question 4 - "I understand the fundamental models generated by fuzzy and SA. I understand why fuzzy and SA are helpful for engineering applications". (Outcome k). Outcome (k): An ability to use the techniques, skills, and modern engineering tools necessary for electrical engineering practice. In post-project, student survey shows that $83.3 \%$ students strongly agreed and $16.7 \%$ students agreed with the statement, "I understand the fundamental models generated by fuzzy and SA. I understand why fuzzy and SA are helpful for engineering applications". $66.7 \%$ students strongly agreed with the statement and $33.7 \%$ students disagreed before completion of project.

5. Question 5 - "I have effective communication skills in the context of a collaborative, multidisciplinary design activity". (Outcome g). Outcome (g): An ability to communicate effectively. In post-project, student survey shows that $83.3 \%$ students strongly agreed and $16.7 \%$ students agreed with the statement, "I have effective communication skills in the context of a collaborative, multi-disciplinary design activity". 50\% students agreed with the statement, $16.7 \%$ students agreed, $16.7 \%$ students disagreed, and $16.7 \%$ students were neutral with the statement before completion of project.

6. Question 6 - "I can create professional documentation in connection with the lab assignments and design projects". (Outcome g). Outcome (g): An ability to communicate effectively. In post-project, student survey shows that $100 \%$ students strongly agreed with the statement, "I have effective communication skills for a collaborative, team-based design project and presentation skills to effectively present my project". $66.7 \%$ students agreed with the statement, and $16.7 \%$ students were neutral and disagreed with the statement, respectively, before completion of project. Documenting and reporting skills are extremely indispensable for student research, which is one of most important training factors in project-based course.

The assessment questionnaire and interview results before and after project are summarized in Table 4. The instructor distributed the questionnaire and collected them from students. In comparison with learning outcomes before and after project, the average effectiveness scores of learning outcomes increase from $58.3 \%$ to $86.1 \%$. The final project and presentation were 
evaluated, which cover some criteria such as communication skills, capability to design and develop algorithms, ability to apply theoretical concepts into electrical systems, capability to solve the engineering issues, and multi-disciplinary team skills. In Figure 2, it illustrates that most students strongly or agree with the statement indicated in the subjects representing ABET outcomes (e), (c), $(\mathrm{k})$ and $(\mathrm{g})$. It is interesting that students are more comfortable with their engineering design capability, problem-resolving ability and understanding engineering system aspects than their communication skills and ability to use techniques to engineering issues. Furthermore, the genetic algorithms in Question 3 (outcome k) are more difficult to understand in comparison with other algorithms such as simulated annealing and fuzzy logic, which are depicted by self-assessment and interviews in Figure 2.

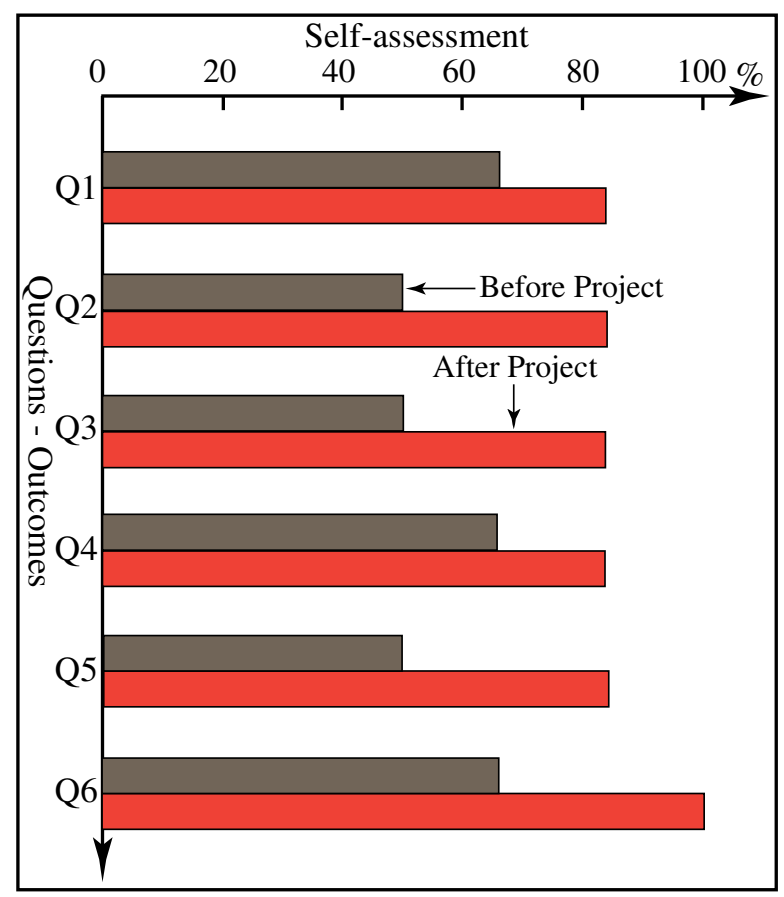

Figure 2 Self-assessment comparison of before and after projects

The interviews are conducted in two stages to have assessment survey. One is on the time point after the concepts have been introduced during classroom discussions and before implementation of project. It assesses how students understand the concepts ready for the research project implementation. The other is on the time point after implementation of project when students had better understanding of dealing with research aspects by concepts introduced in the classroom. In Table 4, comparison of questionnaire survey of ELEE4400/5400 projects reveals that these programming-based research projects grant better learning experience on their electrical engineering research. The quantitative and qualitative questionnaires are acquired to have in-depth insight to student learning quality. As a result, it is noted that the students after undertaking research projects have better feelings on their performance than before implementation of project. The self-assessment comparison before and after students performed research projects is illustrated 
in Fig 2. Based on the self-assessment (in Figure 2) and evaluation by the instructors, student performance with regard to project development has been improved gradually.

Table 4 The questionnaire of students for assessment of education quality

\begin{tabular}{|c|c|c|c|c|c|c|c|c|}
\hline \multirow{2}{*}{$\begin{array}{l}\text { Question } \\
\text { and } \\
\text { Outcome }\end{array}$} & \multicolumn{4}{|c|}{ Before project } & \multicolumn{4}{|c|}{ After project } \\
\hline & $\begin{array}{l}\text { Strongly } \\
\text { agree }\end{array}$ & Agree & Neutral & Disagree & $\begin{array}{l}\text { Strongly } \\
\text { agree }\end{array}$ & Agree & Neutral & Disagree \\
\hline Q1-e & $66.7 \%$ & $0 \%$ & $16.7 \%$ & $16.7 \%$ & $83.3 \%$ & $16.7 \%$ & $0 \%$ & $0 \%$ \\
\hline Q2-c & $50 \%$ & $0 \%$ & $16.7 \%$ & $33.3 \%$ & $83.3 \%$ & $16.7 \%$ & $0 \%$ & $0 \%$ \\
\hline Q3-k & $50 \%$ & $0 \%$ & $33.3 \%$ & $16.7 \%$ & $83.3 \%$ & $0 \%$ & $16.7 \%$ & $0 \%$ \\
\hline Q4-k & $66.7 \%$ & $0 \%$ & $0 \%$ & $33.3 \%$ & $83.3 \%$ & $16.7 \%$ & $0 \%$ & $0 \%$ \\
\hline Q5-g & $50 \%$ & $16.7 \%$ & $16.7 \%$ & $16.7 \%$ & $83.3 \%$ & $16.7 \%$ & $0 \%$ & $0 \%$ \\
\hline Q6-g & $66.7 \%$ & $0 \%$ & $16.7 \%$ & $16.7 \%$ & $100 \%$ & $0 \%$ & $0 \%$ & $0 \%$ \\
\hline
\end{tabular}

As discussed in previous sections, the research project is evaluated by milestone method and weekly interviews with students. Survey results labeled as "Survey Results" are primarily formed from self-assessment of students and interviews with students. In Figure 3, over milestone and project progress, degree of difficulty is in comparison with completion rate in terms of milestones. Degree of difficulty is intended to measure how difficult students complete the research project whereas completion rate aims to indicate what percentage of work has been fulfilled of the project by a deadline. In Figure 3, it reveals that lower degree of difficulty usually results in higher completion rate. For instance, Milestone 4, genetic algorithms for motion planning project, generates $80 \%$ completion rate with $95 \%$ degree of difficulty. "Final" in the figure is in the sense that final stage of project outputs final presentation, final demonstration, and final reports, etc.

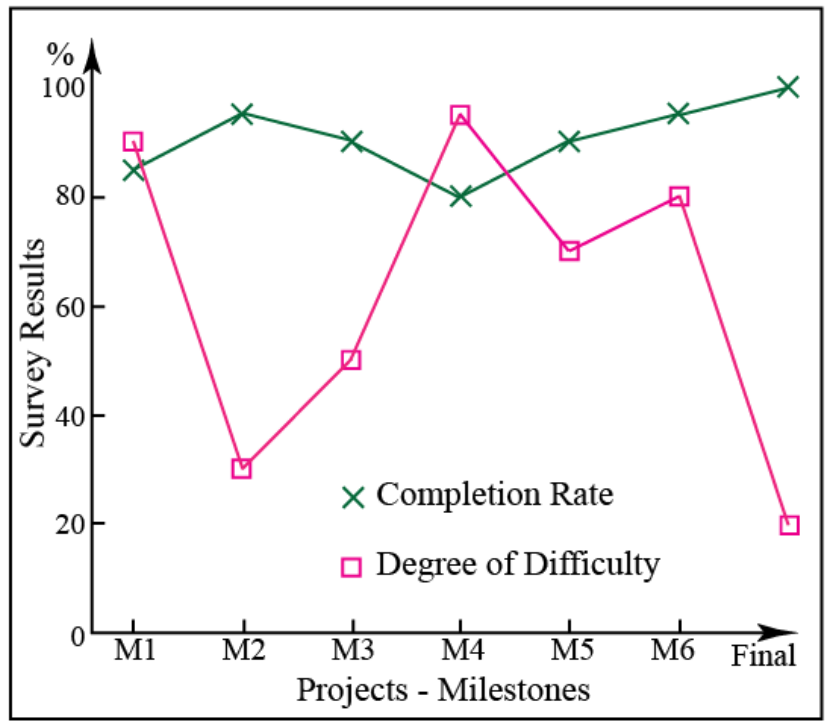

Figure 3 Survey results with regard to degree of difficulty and completion rate of research projects 
Project-based curriculum is intended to compliment the theoretical concepts taught in classroom and reinforce the learning and teaching efficiency focusing on student research in such an algorithm-feature course by providing students with practical research project environments [7-9].

Mills et al [10] addressed benefits and advantages of project-based pedagogy and problem-based learning, which is more efficient than traditional "chalk and talk" pedagogy for engineering education. They also explained difference between project-based and problem-based learning. The project-based pedagogy and mixed model are strongly recommended by authors to be adopted in engineering education in comparison of traditional lecture-centered learning. Our paper extends the above literature of how the on-going project-based pedagogy is implemented to enhance student research capability. Difficulties exist in project-based pedagogy that was examined and explored by Blumenfeld et al [11]. In their paper, they emphasized that project-based learning is largely capable of enhancing motivation, interest and thought in engineering education. The paper proposed an

agenda for research on how the motivation, interest and cognitive engagement can be enhanced. In comparison with these two papers, we have investigated, examined, assessed, and especially, implemented such a project-based pedagogy for enhancement of student research through a semester-long curriculum therefore, some important generalized recommendations can be provided to engineering education community regardless of any courses.

In conclusion, students fulfilled this multiple-project-based course have gathered the following benefits and leaning outcomes. This multiple-project-based new course has

- enhanced the problem-resolving capability by performing the project both independently and collaboratively;

- offered students a great opportunity to obtain extensively programming experience in research project by employing computational intelligence techniques;

- provided students with a sharing atmosphere to communicate effectively, practice team player skills, and work together collaboratively.

- allowed students to implement their project on a weekly basis so as to keep track of project progress to improve their research ability;

- motivated students to attempt any innovative algorithm development, and software programming in the research project;

- trained students to have contain research skills such as knowing current work in field, recognizing research problems, critical thinking, problem-resolving, research methods, critical reviewing, and documenting and reporting;

- taken advantage of a sequence of multi-stage project assignments on the module-based architecture to accelerate the student learning curve in design methodology aspects necessary for the research project.

\section{Discussion and Summary}

In this section, it addresses generalization of this pedagogy beyond this specific Computational Intelligence course. Overall, there has been a greatly positive response to this on-going multiple- 
project-based curriculum to assist students in inspiring their research interest, strengthening their research ability and developing their research potential.

There are some generalized benefits of adopting on-going multiple-project-based pedagogy extracted from this specific course. This kind of pedagogy generally dedicates to most engineering courses. Beyond this course, this pedagogy provides a general guidance for any engineering curriculum with the following aspects.

1. On-going multiple-project-based pedagogy allows lectures to be revised based on students' mistakes, feedbacks, and performance of sub-projects, to better enhance research capability of students.

2. On-going multiple-project-based pedagogy ensures instructors to better keep track of progress and performance of students with regard to research practice. In this way, the entire project can be successfully fulfilled more effectively.

3. On-going multiple-project-based pedagogy assures instructors to carry out allocation of research work in a more reasonable manner, which fosters inquiry abilities, insight and knowledge. Project selection should be based on its validity and feasibility, and adaptability.

4. On-going multiple-project-based pedagogy allows students better establish their selfconfidence in research work. It makes students to better understand the project. Students can understand what the objective of project is, what knowledge the project uses, what skills the project requires, and finally what goal the project achieves.

5. The role of instructors remains critical in the initial orientation to help student decompose the project into sub-projects reasonably. Discussion with students in definition of project tasks aims to reinforce students' skills in planning, scheduling and organization of research project. It is noted that instructors should design, define, prepare and organize the subprojects carefully.

6. On-going Multiple-project-based pedagogy allows students to gain their knowledge and experience of research conception gradually by means of step-by-step sub-projects.

Regardless of any on-going project-based engineering curriculum, generally, this on-going multiple-project-based pedagogy should consist of five stages to implement it, which us applicable for general engineering courses.

Step 1 Formulation of project objective. In this stage, the instructors aid students to perform detailed research project analysis, and make students understand the background of the project. Students should understand the objective this project would achieve.

Step 2 Development of project management plan. Students and instructors work together to decompose the whole project into a series of sub-projects as modules. According to the requirements of sub-projects, schedule the modules and determine the project plan.

Step 3 Implementation of project. Students carry out the project by fulfilling a series of subprojects with supervision and direction by instructors. Instructors revise the project requirements and lecture materials based on last student performance of milestone. 
Step 4 Assessment and evaluation of project. Students assess their milestone work first followed by mainly inspection by the instructor to see if team has achieved the milestones goal. Based on the progress of milestone, the new schedule and plan are determined for the next milestone to assure the better performance of project.

Step 5 Summary of project. In the procedure of sub-projects, instructors assist students in summarizing the milestone, finding unsolved issues, communication with others, training problem resolving skills, and modifying design methodology, to ensure smooth project progress.

Step 6 Documentation and demonstration of project. In this stage, instructors direct students to write final project report, deliver final presentation, and demonstrate their project.

\section{Conclusions}

This paper presented active learning and pedagogy carried out in a project-based Computational Intelligence Techniques course by an on-going research-centered project development in terms of real-time autonomous robot navigation and mapping. This paper described a new successful course curriculum development that dedicates to enhancing the quality of student research by project-based pedagogy. Evidence was presented in this paper that an on-going project-based methodology can effectively improve student learning in the senior-level and graduate level semester-long Computational Intelligence Technique course. A milestone methodology is utilized to keep track of the on-going project progress. Satisfactory performance was evaluated by various milestone assignments, projects, presentation and other activities. Generally, on-going multi-project-based education combined effective classroom lectures, student active learning, innovative pedagogies, project management, and team work, benefits for both student research involvement, and engineering curriculum.

\section{References}

1. Subbian, V., Purdy, C. C., and Beyette, F. R., UnLecture: A Novel Active Learning Based Pedagogical Strategy for Engineering Courses, Proceedings of the 2014 American Society for Engineering Education Annual Conference \& Exposition, ASEE 2014.

2. Rios, E. F., Khan, A. S., and Padgett, D. V., A Senior Design Project: Heating and Cooling System for Car's Interior. Proceedings of the 2014 American Society for Engineering Education Annual Conference \& Exposition, ASEE 2014.

3. Lumpp J., Jacob J., Smith S., Smith W., BIG BLUE: A Multidisciplinary Capstone Engineering Design Project, Proceedings of the 2006 American Society for Engineering Education Annual Conference \& Exposition, ASEE 2006.

4. Lin, Y., Learning from Energy Conversion Related Capstone Projects, Proceedings of the 2010 American Society for Engineering Education Annual Conference \& Exposition, ASEE 2010. 
5. Scott, W. R. Scott and Goktas, R. K. Exploring Engineering Graduate Student Research Proficiency with Student Surveys, Journal of Engineering Education, July 2010, pp.263278.

6. ABET, Criteria for Accrediting Engineering Programs, Baltimore, MD, Engineering Accreditation Commission, October 29, 2011.

7. Prince, M., \& Felder, R. M. (2006). Inductive teaching and learning methods: Definitions, comparisons, and research bases. Journal of Engineering Education, 95(2), pp.123-138.

8. Wertz, R. E. H., Purzer, S., Fosmire, M. J. and Cardella, M. E., Assessing Information Literacy Skills Demonstrated in an Engineering Design Task, Journal of Engineering Education, 102(4), pp. 577-602, 2013.

9. Garcia, O. N., Varanasi, M. R., Acevedo, M. F., and Guturu, P., An Innovative Project and Design Oriented Electrical Engineering Curriculum at the University of North Texas, Advances in Engineering Education, Summer 2011.

10. Mills, Julie E., and David F. Treagust. Engineering education-Is problem-based or projectbased learning the answer? Australasian Journal of Engineering Education 3(2), 2003.

11. E. Soloway, R. W. Marx, J. S. Krajcik, M. Guzdial and A. Palincsar, Motivating projectbased learning: Sustaining the doing, supporting the learning. Educational psychologist 26(3-4), 369-398, 1991. 